\title{
Influence of a reduced length of lighting on the feeding behaviour of fattening rabbits
}

\author{
Y. REYNE, M. PRUD'HON et J. ANGEVAIN \\ Station de Physiologie animale, I.N.R.A., \\ E.N.S.A., Place I'iala, 37060 Montpellier Cedex (France)
}

The influence of a reduced length of lighting on the feeding behaviour characteristics (ingested amounts, frequence and mean weight of the intakes, circadian distribution) were studied in 9 fattening New Zealand white rabbits.

The young rabbits received light ${ }_{4} 4$ hours a day during 5 weeks, then only 8 hours a day during 4 weeks.

The change in lighting times did not modify durably the quantitative characteristics of the feed and water consumption, though the intake of water was more disturbed than that of feed.

The distribution of the consumption over the 24 hours cycle changed progressively towards an adaptation to the new time schedule within about 4 weeks in the case of the feed.

As for the drinking water, the adaptation was not quite finished after four weeks.

$$
\text { II. - FEEDING }
$$

\section{Study of sodium, potassium and chloride requirements in the growing rabbit}

\author{
P. SURDEAU, R. HENAFF, (;. PERRIER, G. BROSSARD et c. IDESTIGNES \\ Chaire de Productions Animales, E.N.I.T.A. de Dijon, \\ 2I80o Quetigny (France)
}

During 3 experimental series corresponding to i 8 treatments, the authors varied the sodium, chloride and potassium contents of a semi-purified diet, while keeping constant the other mineral components. The performances of growing rabbits (between the age of 35 and 84 or 90 days) were studied. The growth rate, feed intake and integrity of the kidneys were studied in growing rabbits. Depending on the $\mathrm{Na}, \mathrm{K}$ and $\mathrm{Cl}$ contents and balances, the growth was much more affected than the feed consumption. Roughly the variation of the feed efficiency was parallel to that of the growth. The potassium rich diets (from r.03 to I.92 p. roo) led, in the alssence of a large sodium supply to severe renal lesions, without any change in the growth rate. For the growing young, the authors sugrgest the following standards: $\mathrm{Na}: 0.4 \mathrm{p}$. roo; $\mathrm{K}:$ r.3 p. roo; cl : 0.4 p. roo. But for breeding animals and future breeding animals the contents should be reduced to $\mathrm{Na}: 0.25$ p. I00; $\mathrm{K}: 0.75 \mathrm{p} .100$ and $\mathrm{Cl}: 0.20$ to $0.25 \mathrm{p}$. Ioo of the diet. 